DOI: $10.15193 /$ zntj/2018/114/226

\author{
MICHAŁ HALAGARDA, JOANNA PTASIŃSKA-MARCINKIEWICZ, \\ KAMIL FIJOREK
}

\title{
A COMPARISON OF MINERAL ELEMENTS CONTENT IN CONVENTIONAL AND ORGANIC MILK FROM SOUTHERN POLAND
}

\begin{abstract}
S u m m a ry
Milk is one of the most important foodstuffs and raw materials in the food industry. As the first complete food available to infant mammals, it is bioactive and it contains all the indispensable nutrients. Organic farming is deemed to produce high quality food under sustainable conditions and, at the same time, to protect the natural environment within the farm. However, the most recent food and nutrition research does not confirm the extensive health benefits related to the consumption of organic products. The objective of the research study was to evaluate and compare the quality of commercial organic and conventional cow's milk as regards the contents of some selected mineral compounds. The research was conducted on the organic and conventional cow's milk available on the market in Southern Poland. The milk samples were analysed for the concentration of selected minerals contained therein, including some selected toxic metals; the analyses were performed with the use of flame atomic absorption spectrometry, atomic emission spectrometry, and graphite furnace atomic absorption spectrometry. The results of the research show that, in terms of the contents of micro- and macroelements, the organic and conventional milk do not differ significantly. The differences were found only between the amounts of sodium and manganese. The organic milk contained, on average, a statistically significantly smaller amount of those elements. Moreover, the presence of lead was detected in one type of the organic milk, although its amount determined (5.24 mg/l) was within the acceptable limits. Cadmium (amounting to 0.12 and $0.15 \mu \mathrm{g} / \mathrm{l}$ ) was found in the two types of milk derived from the same company and in one type of organic milk; however, its concentration in the latter milk type was at a relatively low level $(0.04 \mu \mathrm{g} / \mathrm{l})$.
\end{abstract}

Key words: cow's milk, nutritional value, metals, nutrients, organic food

\section{Introduction}

Milk is one of the most important foodstuffs and raw materials in the food industry. As the first complete food available to infant mammals, it is bioactive and it con-

Dr inż. M. Halagarda, dr inż. J. Ptasińska-Marcinkiewicz, dr inż. K. Fijorek, Katedra Towaroznawstwa Żywności, Wydz. Towaroznawstwa i Zarzadzania Produktem, Uniwersytet Ekonomiczny w Krakowie, ul.Sienkiewicza 5, 30-033 Kraków.Kontakt:michal.halagarda@uek.krakow.pl 
tains all the necessary nutrients. It is a source of proteins, fats, sugars, vitamins, and major minerals $[16,36]$. The production of cow's milk still dominates the world market [32]. Industrial methods are targeted at receiving the highest yield at the lowest cost. Therefore, the trend towards organic production is still gaining in popularity.

The aim of organic farming is to produce the good quality food under the sustainable conditions. An organic farm should be similar to an organism, where the plant production satisfies the needs of livestock production and vice versa. The organic farm should also have one important feature: it should limit the use of external production means (from the outside of the farm) to the lowest possible extent. Therefore, heavy metals, which are persistent contaminants in the environment, should not enter milk at any of the production stages. However, milk can be contaminated either through food and water given to animals or during the manufacturing and packaging processes [1].

The content of macroelements in milk is mainly determined by the period of lactation, udder diseases and, to a lesser degree, by environmental factors. In contrast, the content of trace elements and toxic metals depends largely on nutrition [42]. Therefore, the concentrations of some heavy metals in milk differ depending on the level of pollutions in the breeding area. Additionally, packaging and technological processes used to produce dairy products can significantly increase the concentration of lead and cadmium [11].

The quality control in organic farming does not focus on the final product but on the production process, as it is assumed that the quality of food depends on the method and the conditions of production. Final products are controlled only if reasonable doubts and suspicions exist [26]. Many people, though, wonder if organic foods are actually healthier and have better quality than the conventional ones.

The most current food research does not confirm the extensive health benefits related to consuming organic products $[9,10,15,25,38]$. Thus, the objective of this study was to evaluate the possible differences and to compare the quality of commercial organic and conventional cow's milk in reference to its mineral elements. Assessing them is essential for the evaluation of the nutritional integrity of food [8]. The research also aims to add new data to the knowledge on the properties of organic food products and, thus, to provide valuable information for consumers. To achieve the objective, a following hypothesis was formulated: the commercial organic milks differ significantly from the commercial conventional milks as regards to the content of mineral elements.

\section{Material and methods}

The research was conducted on the organic and conventional cow's milk available on the market in Southern Poland. Four organic and four conventional varieties of milks produced in Poland were analysed. All the milk samples came from 3 production 
batches (purchased in May, July, September) and they were analysed in triplicate. The conventional types of milk are commonly available on the Polish market and were purchased in supermarkets (samples A, B, C, D). Organic milk samples were purchased in small organic shops and in hypermarkets that accommodate stands with the organic food. One type of the organically labelled milks was raw $(\mathrm{H})$ milk coming from a certified organic farm; it was sold in southern and central Poland. The rest of them were pasteurized milks (E, F, G) produced by the dairy factories located in Poland. Milks $\mathrm{E}$ and $\mathrm{H}$ were not standardised. The milk samples were packed in 11 multilayer laminate boxes (samples A and C), 11 (samples B, D, E, F) and 0.91 (sample G) PET bottles, and in 0.751 glass bottles (sample H). The average compositions of milk varieties are presented in Tab. 1 .

Table 1. Chemical composition of milk analysed

Tabela 1. Skład chemiczny badanego mleka

\begin{tabular}{|c|c|c|c|c|c|c|c|c|}
\hline \multirow{2}{*}{$\begin{array}{l}\text { Parameter } \\
\text { Parametr }\end{array}$} & \multicolumn{8}{|c|}{ Milk / Mleko } \\
\hline & A & $\mathrm{B}$ & $\mathrm{C}$ & $\mathrm{D}$ & $E$ & $\mathrm{~F}$ & $\mathrm{G}$ & $\mathrm{H}$ \\
\hline $\begin{array}{l}\text { Source } \\
\text { Źródło }\end{array}$ & \multicolumn{4}{|c|}{$\begin{array}{c}\text { Conventional } \\
\text { Konwencjonale }\end{array}$} & \multicolumn{4}{|c|}{$\begin{array}{c}\text { Organic } \\
\text { Ekologiczne }\end{array}$} \\
\hline $\begin{array}{c}\text { Total solids } \\
\text { Sucha masa }[\mathrm{g} / 100 \mathrm{~g}] \\
\overline{\mathrm{x}} \pm \mathrm{SD}\end{array}$ & $\begin{array}{l}10.45 \\
\pm 0.40\end{array}$ & $\begin{array}{l}10.96 \\
\pm 0.12\end{array}$ & $\begin{array}{l}11.16 \\
\pm 0.06\end{array}$ & $\begin{array}{l}11.12 \\
\pm 0.11\end{array}$ & $\begin{array}{c}11.74 \\
\pm 0.30\end{array}$ & $\begin{array}{c}11.44 \\
\pm 0.02\end{array}$ & $\begin{array}{r}10.27 \\
\pm 0.04\end{array}$ & $\begin{array}{r}11.63 \\
\pm 0.07\end{array}$ \\
\hline $\begin{array}{c}\text { Non-fat total solids } \\
\text { Sucha masa } \\
\text { beztłuszczowa }[\mathrm{g} / 100 \mathrm{~g}] \\
\overline{\mathrm{x}} \pm \mathrm{SD}\end{array}$ & $\begin{array}{c}7.87 \\
\pm 0.23\end{array}$ & $\begin{array}{c}7.80 \\
\pm 0.13\end{array}$ & $\begin{array}{c}7.97 \\
\pm 0.04\end{array}$ & $\begin{array}{c}7.90 \\
\pm 0.14\end{array}$ & $\begin{array}{c}8.22 \\
\pm 0.44\end{array}$ & $\begin{array}{c}7.90 \\
\pm 0.04\end{array}$ & $\begin{array}{c}8.27 \\
\pm 0.04\end{array}$ & $\begin{aligned} & 7.78 \\
\pm & 0.12\end{aligned}$ \\
\hline $\begin{array}{l}\text { Mineral components in } \\
\text { the form of total ash } \\
\text { Związki mineralne jako } \\
\text { popiół ogółem }[\mathrm{g} / 100 \mathrm{~g}] \\
\quad \overline{\mathrm{x}} \pm \mathrm{SD}\end{array}$ & $\begin{array}{c}0.73 \\
\pm 0.01\end{array}$ & $\begin{array}{c}0.71 \\
\pm 0.01\end{array}$ & $\begin{array}{c}0.72 \\
\pm 0.01\end{array}$ & $\begin{array}{c}0.72 \\
\pm 0.01\end{array}$ & $\begin{array}{c}0.72 \\
\pm 0.01\end{array}$ & $\begin{array}{c}0.70 \\
\pm 0.01\end{array}$ & $\begin{array}{c}0.74 \\
\pm 0.01\end{array}$ & $\begin{array}{c}0.71 \\
\pm 0.01\end{array}$ \\
\hline $\begin{array}{c}\text { Lactose } \\
\text { Laktoza }[\mathrm{g} / 100 \mathrm{~g}] \\
\overline{\mathrm{x}} \pm \mathrm{SD}\end{array}$ & $\begin{array}{c}4.02 \\
\pm 0.03\end{array}$ & $\begin{array}{c}3.71 \\
\pm 0.31\end{array}$ & $\begin{array}{c}3.92 \\
\pm 0.08\end{array}$ & $\begin{array}{c}3.91 \\
\pm 0.48\end{array}$ & $\begin{array}{c}3.77 \\
\pm 0.48\end{array}$ & $\begin{array}{c}3.95 \\
\pm 0.13\end{array}$ & $\begin{array}{c}3.99 \\
\pm 0.17\end{array}$ & $\begin{array}{c}4.01 \\
\pm 0.13\end{array}$ \\
\hline $\begin{array}{c}\text { Protein } \\
\text { Białko }[\mathrm{g} / 100 \mathrm{~g}] \\
\overline{\mathrm{x}} \pm \mathrm{SD}\end{array}$ & $\begin{array}{c}3.48 \\
\pm 0.13\end{array}$ & $\begin{array}{c}3.31 \\
\pm 0.30\end{array}$ & $\begin{array}{c}3.43 \\
\pm 0.23\end{array}$ & $\begin{array}{c}3.49 \\
\pm 0.14\end{array}$ & $\begin{array}{c}3.53 \\
\pm 0.02\end{array}$ & $\begin{array}{c}3.46 \\
\pm 0.11\end{array}$ & $\begin{array}{c}3.81 \\
\pm 0.15\end{array}$ & $\begin{array}{l}3.30 \\
\pm 0.07\end{array}$ \\
\hline $\begin{array}{c}\text { Casein } \\
\text { Kazeina }[\mathrm{g} / 100 \mathrm{~g}] \\
\overline{\mathrm{x}} \pm \mathrm{SD}\end{array}$ & $\begin{array}{c}2.36 \\
\pm 0.16\end{array}$ & $\begin{array}{c}2.33 \\
\pm 0.17\end{array}$ & $\begin{array}{c}2.43 \\
\pm 0.08\end{array}$ & $\begin{array}{c}2.41 \\
\pm 0.20\end{array}$ & $\begin{array}{c}2.51 \\
\pm 0.20\end{array}$ & $\begin{array}{c}2.38 \\
\pm 0.19\end{array}$ & $\begin{array}{c}2.51 \\
\pm 0.14\end{array}$ & $\begin{array}{c}2.51 \\
\pm 0.12\end{array}$ \\
\hline
\end{tabular}

Explanatory notes / Objaśnienia:

A - H - codes of milk samples analysed / kody próbek analizowanego mleka; $\overline{\mathrm{x}}$ - mean value / wartość średnia; SD - standard deviation / odchylenie standardowe; $\mathrm{n}=3$. 
The milk samples were analysed for the concentration of selected minerals, including the content of specifically selected toxic metals. The analysis methods differed depending on the examined components and in particular they involved:

- flame atomic absorption spectrometry to determine the contents of $\mathrm{Zn}$ and $\mathrm{Mg}$,

- atomic emission spectrometry with atomization in flame to determine the contents of $\mathrm{K}, \mathrm{Na}, \mathrm{Ca}$,

- graphite furnace atomic absorption spectrometry to determine the contents of $\mathrm{Cd}$, $\mathrm{Pb}, \mathrm{Mn}, \mathrm{Cu}, \mathrm{Fe}$.

The atomic absorption spectrometry was performed with the use of Perkin-Elmer AAnalyst 800 spectrometer (Waltham, USA) - Zn, Mg, Cd, Pb, Mn, Cu, Fe and the atomic emission spectrometry using a Jenway PFP7 spectrometer (Staffordshire, United Kingdom) - K, Na, Ca. The $0.5 \mathrm{~g}$ milk samples were mineralized in a mixture of nitric and perchloric acids at the ratio of $4: 1$, at $150{ }^{\circ} \mathrm{C}$ in a Milestone Start D microwave (Sorisole, Italy). In the case of $\mathrm{Na}, \mathrm{K}, \mathrm{Mg}, \mathrm{Ca}$, the solutions were first diluted 100 times and in the case of $\mathrm{Fe}, \mathrm{Cu}, \mathrm{Zn}, \mathrm{Mn}, \mathrm{Cd}, \mathrm{Pb}-5$ times. In addition to the milk samples, the blank and reference samples were also analysed. Deionised water samples were analysed to determine the level of method sensitivity. The detection levels for cadmium and lead were 0.074 and $0.524 \mu \mathrm{g} / 1$, respectively.

A one-way ANOVA followed by pairwise t-test was used to compare means of the research results. A value of 0.05 was required for the statistical significance. A statistical data analysis was performed with the use of Statistica 12.0 (Statsoft, Tulusa, USA) software.

\section{Results and discussion}

The results of the analysis of the selected micro- and macroelements in the milk samples are presented in Tab. 2.

\section{Calcium}

The content of calcium in milk is particularly important. It is crucial not only because of its good bioavailability by the human body but also owing to the technological reasons. It is also an indicator of hygiene (in the udders disease, among other symptoms, the content of calcium decreases). The calcium content ranged from $822 \mathrm{mg} / \mathrm{l}$ in milk $\mathrm{G}$ to $938 \mathrm{mg} / \mathrm{l}$ in milk E. The statistical analysis showed some significant differences in the content of calcium between the analysed milk samples. They consisted in the discrepancies between the samples containing the lowest amount of calcium and the samples with the highest calcium content. According to Bergamo et al. [3] and Butler et al. [7], milk from the certified organic farms contains more calcium. Nevertheless in the present research as regards the concentrations of calcium, no statistically 
Table 2. Content of toxic metals, micro- and macroelements in milk analysed

Tabela 2. Zawartość metali toksycznych oraz mikro- i makroelementów w analizowanym mleku

\begin{tabular}{|c|c|c|c|c|c|c|c|c|}
\hline \multirow[b]{2}{*}{$\begin{array}{c}\text { Element } \\
\text { Pierwiastek }\end{array}$} & \multicolumn{8}{|c|}{ Milk / Mleko } \\
\hline & $\begin{array}{c}\mathrm{A} \\
(\mathrm{n}=3)\end{array}$ & $\begin{array}{c}\mathrm{B} \\
(\mathrm{n}=3)\end{array}$ & $\begin{array}{c}C \\
(n=3)\end{array}$ & $\begin{array}{c}\mathrm{D} \\
(\mathrm{n}=3)\end{array}$ & $\begin{array}{c}\mathrm{E} \\
(\mathrm{n}=3)\end{array}$ & $\begin{array}{c}\mathrm{F} \\
(\mathrm{n}=3)\end{array}$ & $\begin{array}{c}\mathrm{G} \\
(\mathrm{n}=3)\end{array}$ & $\begin{array}{c}\mathrm{H} \\
(\mathrm{n}=3)\end{array}$ \\
\hline $\begin{array}{l}\text { Source } \\
\text { Źródło }\end{array}$ & \multicolumn{4}{|c|}{$\begin{array}{l}\text { Conventional / Konwencjonalne } \\
\qquad(\mathrm{n}=12)\end{array}$} & \multicolumn{4}{|c|}{$\begin{array}{l}\text { Organic / Ekologiczne } \\
\qquad(\mathrm{n}=12)\end{array}$} \\
\hline \multirow{2}{*}{$\begin{array}{c}\mathrm{Ca}[\mathrm{mg} / \mathrm{l}] \\
\overline{\mathrm{x}} \pm \mathrm{SD}\end{array}$} & $\begin{array}{c}882 \\
\pm 42.7\end{array}$ & $\begin{array}{r}863^{\mathrm{a}} \\
\pm 12.8\end{array}$ & $\begin{array}{l}909^{\mathrm{bc}} \\
\pm 31.5\end{array}$ & $\begin{array}{l}904^{\mathrm{de}} \\
\pm 22.5\end{array}$ & $\begin{array}{l}938^{\text {afg }} \\
\pm 35.4\end{array}$ & $\begin{array}{l}827^{\text {bdth }} \\
\pm 23.5\end{array}$ & $\begin{array}{l}822^{\text {cegi }} \\
\pm 25.6\end{array}$ & $\begin{array}{l}911^{\mathrm{hi}} \\
\pm 28.8\end{array}$ \\
\hline & \multicolumn{4}{|c|}{$890 \pm 31.6$} & \multicolumn{4}{|c|}{$874 \pm 58.4$} \\
\hline $\mathrm{P}$ & \multicolumn{8}{|c|}{0.439} \\
\hline \multirow{2}{*}{$\begin{array}{l}\mathrm{K}[\mathrm{mg} / \mathrm{l}] \\
\overline{\mathrm{x}} \pm \mathrm{SD}\end{array}$} & $\begin{array}{c}1517 \\
\pm 82.8\end{array}$ & $\begin{array}{c}1487 \\
\pm 72.3\end{array}$ & $\begin{array}{c}1552 \\
\pm 62.2\end{array}$ & $\begin{array}{c}1482 \\
\pm 53.0\end{array}$ & $\begin{array}{l}1534^{\mathrm{a}} \\
\pm 45.4\end{array}$ & $\begin{array}{l}1382^{\mathrm{abc}} \\
\pm 61.4\end{array}$ & $\begin{array}{l}1622^{b} \\
\pm 45.1\end{array}$ & $\begin{array}{l}1536^{\mathrm{c}} \\
\pm 47.3\end{array}$ \\
\hline & \multicolumn{4}{|c|}{$1510 \pm 65.3$} & \multicolumn{4}{|c|}{$1518 \pm 100$} \\
\hline $\mathrm{P}$ & \multicolumn{8}{|c|}{0.808} \\
\hline \multirow{2}{*}{$\begin{array}{c}\mathrm{Na}[\mathrm{mg} / \mathrm{l}] \\
\overline{\mathrm{x}} \pm \mathrm{SD}\end{array}$} & $\begin{array}{c}504 \\
\pm 39.7\end{array}$ & $\begin{array}{c}501 \\
\pm 26.5\end{array}$ & $\begin{array}{c}438 \\
\pm 43.7\end{array}$ & $\begin{array}{c}520 \\
\pm 39.8\end{array}$ & $\begin{array}{c}446 \\
\pm 46.6\end{array}$ & $\begin{array}{c}427 \\
\pm 37.1\end{array}$ & $\begin{array}{c}485 \\
\pm 30.4\end{array}$ & $\begin{array}{c}453 \\
\pm 50.3\end{array}$ \\
\hline & \multicolumn{4}{|c|}{$491 \pm 46.0$} & \multicolumn{4}{|c|}{$453 \pm 41.8$} \\
\hline $\mathrm{P}$ & \multicolumn{8}{|c|}{0.046} \\
\hline \multirow{2}{*}{$\begin{array}{c}\mathrm{Mg}[\mathrm{mg} / \mathrm{l}] \\
\overline{\mathrm{x}} \pm \mathrm{SD}\end{array}$} & $\begin{array}{c}117 \\
\pm 17.1\end{array}$ & $\begin{array}{c}110 \\
\pm 12.1\end{array}$ & $\begin{array}{c}120 \\
\pm 15.6\end{array}$ & $\begin{array}{c}115 \\
\pm 9.85\end{array}$ & $\begin{array}{c}124 \\
\pm 12.7\end{array}$ & $\begin{array}{c}104 \\
\pm 12.9\end{array}$ & $\begin{array}{c}125 \\
\pm 14.8\end{array}$ & $\begin{array}{c}117 \\
\pm 9.31\end{array}$ \\
\hline & \multicolumn{4}{|c|}{$115 \pm 12.4$} & \multicolumn{4}{|c|}{$117 \pm 13.9$} \\
\hline $\mathrm{P}$ & \multicolumn{8}{|c|}{0.711} \\
\hline \multirow{2}{*}{$\begin{array}{c}\mathrm{Zn}[\mathrm{mg} / \mathrm{l}] \\
\overline{\mathrm{x}} \pm \mathrm{SD}\end{array}$} & $\begin{array}{l}3.25^{\mathrm{ab}} \\
\pm 0.27\end{array}$ & $\begin{array}{l}3.07^{\text {cde }} \\
\pm 0.22\end{array}$ & $\begin{array}{l}2.80^{\text {fgh }} \\
\pm 0.19\end{array}$ & $\begin{array}{l}3.95^{\text {acfij }} \\
\pm 0.16\end{array}$ & $\begin{array}{l}3.89^{\mathrm{dgkT}} \\
\pm 0.34\end{array}$ & $\begin{array}{c}3.08^{\mathrm{ikmn}} \\
\pm 0.21\end{array}$ & $\begin{array}{c}3.91^{\text {ehmo }} \\
\pm 0.34\end{array}$ & $\begin{array}{c}2.49^{\text {bjho }} \\
\pm 0.35\end{array}$ \\
\hline & \multicolumn{4}{|c|}{$3.27 \pm 0.48$} & \multicolumn{4}{|c|}{$3.34 \pm 0.68$} \\
\hline $\mathrm{P}$ & \multicolumn{8}{|c|}{0.757} \\
\hline \multirow{2}{*}{$\begin{array}{c}\mathrm{Fe}[\mu \mathrm{g} / \mathrm{l}] \\
\overline{\mathrm{x}} \pm \mathrm{SD}\end{array}$} & $\begin{array}{c}668^{\text {abcdefg }} \\
\pm 90.1\end{array}$ & $\begin{array}{c}443^{\text {ahijkm }} \\
\pm 93.8\end{array}$ & $\begin{array}{c}189^{\mathrm{bh}} \\
\pm 24.9\end{array}$ & $\begin{array}{c}214^{\mathrm{ci}} \\
\pm 45.1\end{array}$ & $\begin{array}{c}188^{\mathrm{dj}} \\
\pm 22.6\end{array}$ & $\begin{array}{c}223^{\mathrm{ek}} \\
\pm 24.7\end{array}$ & $\begin{array}{c}208^{\mathrm{fl}} \\
\pm 27.7\end{array}$ & $\begin{array}{l}220^{\mathrm{gm}} \\
\pm 17.7\end{array}$ \\
\hline & \multicolumn{4}{|c|}{$378 \pm 212$} & \multicolumn{4}{|c|}{$210 \pm 24.5$} \\
\hline $\mathrm{P}$ & \multicolumn{8}{|c|}{0.019} \\
\hline $\mathrm{Cu}[\mu \mathrm{g} / \mathrm{l}]$ & $\begin{array}{c}50.6 \\
\pm 12.0\end{array}$ & $\begin{array}{c}46.3 \\
\pm 9.32 \\
\end{array}$ & $\begin{array}{c}51.8 \\
\pm 8.56 \\
\end{array}$ & $\begin{array}{c}53.0 \\
\pm 9.27\end{array}$ & $\begin{array}{c}62.7^{\mathrm{a}} \\
\pm 7.78 \\
\end{array}$ & $\begin{array}{c}41.6 \\
\pm 8.22 \\
\end{array}$ & $\begin{array}{c}50.2 \\
\pm 14.0\end{array}$ & $\begin{array}{c}39.9^{\mathrm{a}} \\
\pm 9.29\end{array}$ \\
\hline & & 50.4 & 8.84 & & & 48.6 & 12.8 & \\
\hline $\mathrm{P}$ & & & & & & & & \\
\hline $\operatorname{Mn}[\mu \mathrm{g} / \mathrm{l}]$ & $\begin{array}{c}28.3 \\
\pm 6.45 \\
\end{array}$ & $\begin{array}{c}28.7 \\
\pm 3.71 \\
\end{array}$ & $\begin{array}{c}23.7 \\
\pm 4.34 \\
\end{array}$ & $\begin{array}{c}26.0 \\
\pm 2.16 \\
\end{array}$ & $\begin{array}{c}22.5 \\
\pm 3.01\end{array}$ & $\begin{array}{c}23.0 \\
\pm 1.80\end{array}$ & $\begin{array}{c}25.8 \\
\pm 5.06\end{array}$ & $\begin{array}{c}22.3 \\
\pm 2.92\end{array}$ \\
\hline $\mathrm{X} \pm \mathrm{SD}$ & & 26.7 & 4.33 & & & 23.4 & 3.26 & \\
\hline $\mathrm{P}$ & & & & & & & & \\
\hline $\mathrm{Pb}[\mu \mathrm{g} / 1]$ & bdl & bdl & bdl & bdl & bdl & $\begin{array}{c}5.24 \\
\pm 3.38\end{array}$ & bdl & bdl \\
\hline $\mathrm{X} \pm \mathrm{SD}$ & & 0.00 & 0.00 & & & 1.31 & 2.77 & \\
\hline $\mathrm{P}$ & & & & & & & & \\
\hline $\mathrm{Cd}[\mu \mathrm{g} / 1]$ & $\begin{array}{c}0.12 \\
\pm 0.06\end{array}$ & $\begin{array}{c}0.15 \\
\pm 0.03\end{array}$ & bdl & bdl & bdl & bdl & bdl & bdl \\
\hline $\mathrm{x} \pm \mathrm{SD}$ & & 0.07 & 0.08 & & & 0.01 & 0.02 & \\
\hline $\mathrm{P}$ & & & & & & & & \\
\hline
\end{tabular}

Explanatory notes / Objaśnienia: 
A - H - codes of milk samples analysed / kody próbek analizowanego mleka; $\bar{x}$ - mean value / wartość średnia; SD - standard deviation / odchylenie standardowe; a - $\mathrm{m}$ - mean values in rows denoted by different letters differ statistically significantly $(\mathrm{p} \leq 0.05)$ / wartości średnie $\mathrm{w}$ wierszach oznaczone różnymi literami różnią się statystycznie istotnie przy $\mathrm{p} \leq 0,05$; bdl - below the detection threshold / poniżej progu wykrywalności.

significant differences were reported between the organic and conventional milks (Tab. 2). The heating of milk and $\mathrm{pH}$ changes in the environment cause distortions in the balance of the calcium salts system. The amount of calcium in cow's milk should be between 1000 and $1400 \mathrm{mg} / \mathrm{l}$. The content of this element is primarily affected by: genotype, individual features, state of health of the cow and its diet. In the case of a high deficiency of calcium in the feed, the animal body uses calcium stored in the bones [20, 29]. Grega et al. [19] showed that differences in the calcium content could be attributed to the breed of cows. Due to the fact that the milk analysed was commercial, it is impossible to evaluate the potential effect of the above mentioned factors on the calcium concentration in the samples analysed. However the differences in the content of this element can be attributed to the fact that, except for the product $\mathrm{G}$, the samples analysed were heat-treated. The amounts of calcium similar to those as determined in the study were received by Slačanac et al. for the UHT milk in Croatia $789.5 \mathrm{mg} / 1$ [40]. Other researchers reported higher calcium concentrations in the raw milks analysed: Zuerera-Cosano et al. - $1251 \mathrm{mg} / \mathrm{kg}$ [47] and Sola-Larrańaga and Navarro-Blasco [42] - $970 \mathrm{mg} / \mathrm{l}$ in the Spanish milk; Sikirić et al. [39] - $1403 \mathrm{mg} / \mathrm{kg}$ in the Croatian milk; and Khan et al. [22] - $1085 \mathrm{mg} / \mathrm{kg}$ in the Korean milk.

\section{Potassium}

Unlike calcium, the potassium content in milk is not dependent on the diet. The health condition of an animal, particularly mastitis, has a negative effect on the amount of potassium in milk. Another factor that influences the concentration of this mineral is the period of lactation. Potassium occurs in milk in a fully ionized form and its amount ranges from 1350 to $1550 \mathrm{mg} / \mathrm{l}$. The increase in the sodium content automatically reduces the amount of potassium in milk [20,29]. The results obtained in this research show that the potassium content in the material analysed was relatively high. The lowest quantity of this element was determined in the milk F $(1382 \mathrm{mg} / \mathrm{l})$, and the highest in the milk sample G (1622 mg/l). Among the organic milks, the sample F was characterized by the statistically significantly lowest concentration of potassium. Similarly as in the case of calcium, no statistically significant differences were found in the potassium contents between the organic and conventional milks. Sola-Larrańaga and NavarroBlasco [42] reported, as regards the Spanish raw milk, a lower potassium concentration than that received in this study (1344 mg/l), whereas Khan et al. [22], and Slačanac et 
al. [40] reported even lower amounts (respectively $1195 \mathrm{mg} / \mathrm{kg}$ in the Korean plain milk and $962.3 \mathrm{mg} / \mathrm{l}$ in the Croatian UHT milk).

\section{Sodium}

Sodium chloride and lactose are responsible for maintaining the osmotic pressure of milk at a constant level. Therefore, where the amount of lactose in milk decreases (e.g. inflammation of the udder, final stage of lactation) the level of sodium and chlorine automatically increases. In the milk from healthy cows, the sodium content is in the range from 300 to $600 \mathrm{mg} / 1$ [20, 29, 34]. The sodium content in the samples analysed varied between $427 \mathrm{mg} / \mathrm{l}$ (sample F) and $520 \mathrm{mg} / \mathrm{l}$ (sample D) and this is consistent with the average as indicated in the Polish reference literature. Statistically significant differences concerning sodium concentration were found only between the samples D and F. Nevertheless, the organic milks contained, on average, statistically significantly less sodium than the conventional products (p $0.046<0.05)$ (Tab. 2). Lower sodium concentrations were reported by Sola-Larrańaga and Navarro-Blasco [42] - $372 \mathrm{mg} / \mathrm{l}$ in the Spanish raw milk and by Khan et al. [22] - $256.7 \mathrm{mg} / \mathrm{kg}$ in the South Korean plain milk.

\section{Magnesium}

The amount of magnesium in milk is in strict and directly proportional relation with the amount of calcium. Cow's milk contains, on average, $100 \div 150 \mathrm{mg} / \mathrm{l}$ of this element $[20,29]$. The amounts of magnesium measured in the samples tested varied from $104 \mathrm{mg} / \mathrm{l}$ in the milk F to $125 \mathrm{mg} / \mathrm{l}$ in the milk G. Statistically significant differences were not detected, neither between the single samples of milk nor between the groups of the organic and conventional milks. Similar results to those received in this study were noted by Zuerera-Cosano et al. [47] - $116 \mathrm{mg} / \mathrm{kg}$ in the Spanish raw milk; by Khan et al. [22] $-104.8 \mathrm{mg} / \mathrm{kg}$ in the South Korean plain milk; and by SolaLarrańaga and Navarro-Blasco [42] - $91.8 \mathrm{mg} / \mathrm{l}$ in the Spanish raw milk. Significantly lower and higher concentrations of magnesium were determined in the Croatian milk $62.5 \mathrm{mg} / \mathrm{l}$ (UHT) [40] and $165 \mathrm{mg} / \mathrm{kg}$ (raw) [39].

\section{Zinc}

Zinc is an essential trace element, particularly vital for the metabolic activity of over 400 proteins in the human body. It is considered crucial for the cell division as well as for the synthesis of DNA and proteins [18]. Zinc also plays an important role in the cell-mediated immune functions and as an antioxidant and anti-inflammatory agent [44]. According to the reference literature, the concentration of zinc in the cow's milk fluctuates between 3 and $5 \mathrm{mg} / 1$ [20]. A higher content of that element results mainly from the metal pesticides [24]. The lowest concentration of zinc was noted in the milk $\mathrm{H}(2.49 \mathrm{mg} / \mathrm{l})$, while the highest in the milk D (3.95 mg/l). Some statistically signifi- 
cant differences were found between the analysed samples of milk (Tab. 2); however, no statistically significant differences between the organic and conventional milks were determined. It is worth noting that the raw, organic milk (sample $\mathrm{H}$ ) had the significantly lowest content of zinc as compared to almost all other milks tested. Sikirić et al. [39] determined the content of $0.51 \mathrm{mg} / \mathrm{kg}$ in the Croatian raw milk; Sola-Larrańaga and Navarro-Blasco [42] - $4.63 \mathrm{mg} / \mathrm{l}$ in the Spanish raw milk; Slačanac et al. [40] $3.28 \mathrm{mg} / \mathrm{l}$ in the Croatian UHT milk; and Khan et al. [23] - $3.87 \mathrm{mg} / \mathrm{kg}$ in the skimmed milk and $4.75 \mathrm{mg} / \mathrm{kg}$ in the plain milk in South Korea.

Iron

An excessive amount of iron as well as copper adversely affects the quality of milk. Ions of those elements catalyse the oxidation of some vitamins and fatty acids, and this negatively affects, primarily, the organoleptic characteristics of milk [34]. In this research, the statistically significantly highest iron concentrations were determined in the milks A and B derived from the same producer (respectively 668 and $443 \mu \mathrm{g} / \mathrm{l}$ ). A high concentration of iron in the milk purchased in shops may result from metallic containers used to transport and store milk [33]. The content of this element in all other samples ranged from $188 \mu \mathrm{g} / \mathrm{l}$ (milk E) to $223 \mu \mathrm{g} / \mathrm{l}$ (milk F) and the differences between them were not statistically significant. High concentrations of iron in the milks $\mathrm{A}$ and $\mathrm{B}$ resulted in a statistically significantly higher average concentration of this element in the conventional milks in comparison to the organic milk (p $0.019<0.05)$. As in the case of the samples analysed, the concentration values of iron in milk differ significantly in the reference literature. Sikiric et al. [39] noted the content of $130 \mu \mathrm{g} / \mathrm{kg}$ in the Croatian raw milk; Enb et al. [16] - $682 \mu \mathrm{g} / \mathrm{kg}$ in the Egyptian raw milk; Qin et al. [36] - $1510 \mu \mathrm{g} / \mathrm{kg}$ in the Japanese commercial milk and $2210 \mu \mathrm{g} / \mathrm{kg}$ in the Chinese commercial milk; Sola-Larranaga and Navarro-Blasco [42] - $290 \mu \mathrm{g} / 1$ in the Spanish raw milk; Slačanac et al. [40] $-210 \mu \mathrm{g} / \mathrm{l}$ in the Croatian UHT milk.

Copper

Copper is an element the small amounts of which are required by the human body to function properly. It plays an important role in the vital oxidation-reduction reactions. However, too high concentrations of this metal are toxic. The ranges concerning the amount of this element in cow's, goat's or sheep's milk are very broad [4]. The copper content depends on many factors; especially on the environmental factor and on those connected with the feeding system. Dobrzański et al. [13] showed that cow's milk derived from an unpolluted area contained $228 \mu \mathrm{g} / \mathrm{kg}$ of copper on average, whereas that from a polluted region $659 \mu \mathrm{g} / \mathrm{kg}$. In addition, as demonstrated by Mass et al. [31], the copper concentration can be significantly higher in the processed than in the raw milk owing to the migration of this element from the equipment. In this study, 
the highest and the lowest copper contents were determined in the organic milk samples $(\mathrm{E}$ and $\mathrm{H})$ and for those two milks the differences were statistically significant. The lowest copper concentration was noted in the milk $\mathrm{H}-39.9 \mu \mathrm{g} / 1$, which was raw, and the highest in the milk E (pasteurised) - $62.7 \mu \mathrm{g} / \mathrm{l}$. There were no statistically significant differences in the content of this element between the organic and conventional milks. Dobrzański et al. [12] determined a higher concentration of copper $(89.9 \mu \mathrm{g} / 1)$ in the milk derived from a polluted region in Lower Silesia, Poland, and a similar concentration in the milk from an unpolluted region in Upper Silesia $(65.4 \mu \mathrm{g} / \mathrm{l})$. Moreover, the concentration of copper in the milks analysed is in accordance with some results of the research conducted in various regions of the world. Sola-Larranaga and NavarroBlasco [42] noted the content of $51.8 \mu \mathrm{g} / \mathrm{l}$ in the Spanish raw milk. Other researchers, however, reported significantly higher contents of this element in milk: Sikirić et al. [39] - $380 \mu \mathrm{g} / \mathrm{kg}$ in the Croatian raw milk; Enb et al. [16] - $124 \mu \mathrm{g} / \mathrm{kg}$ in the Egyptian raw milk; Qin et al. [36] - $230 \mu \mathrm{g} / \mathrm{kg}$ in the Japanese commercial milk and $170 \mu \mathrm{g} / \mathrm{kg}$ in the Chinese commercial milk; Bilandžić et al. [4] - $931.9 \mu \mathrm{g} / 1$ in the North - and $848.4 \mu \mathrm{g} / \mathrm{l}$ in the South-Croatian milk; Khan et al. [23] - 383.4 $\mu \mathrm{g} / \mathrm{kg}$ in the South Korean skimmed milk and $84.6 \mu \mathrm{g} / \mathrm{kg}$ in the South Korean plain milk.

\section{Manganese}

On average, the level of manganese in the cow's milk is around $0.02 \div 0.05 \mathrm{mg} / \mathrm{l}$ [20]. The concentration of manganese was at a very similar level in all the analysed milk samples, both organic and conventional. The determined amount of manganese ranged from $22.3 \mu \mathrm{g} / 1$ in the milk $\mathrm{H}$ to $28.7 \mu \mathrm{g} / 1$ in the milk B. The statistical analysis showed no significant differences in the content of manganese between the samples analysed. Nevertheless, the organic milk contained, on average, statistically significantly less manganese than the conventional milk (p $0.047<0.05)($ Tab. 2). The research results are similar to those received by Sola-Larrańaga and Navarro-Blasco [42]. They determined the content of manganese to be $29.1 \mu \mathrm{g} / 1$ in the Spanish raw milk. Higher concentrations of this element were reported by Dobrzański et al. [12] in the Polish raw milk derived from Lower Silesia $(101.8 \mu \mathrm{g} / \mathrm{l})$ and Upper Silesia $(51.2 \mu \mathrm{g} / \mathrm{l})$ as well as by Khan et al. [23] $-64.1 \mu \mathrm{g} / \mathrm{kg}$ in the skimmed and $133.9 \mu \mathrm{g} / \mathrm{kg}$ in the plain milk in South Korea.

\section{Lead and cadmium}

Testing food for contamination with toxic metals has a crucial importance as those elements have a direct impact on human health and life. Their occurrence in the food, no matter what role they play in the animal body, is always undesirable and noxious. Heavy metals can accumulate in tissues and organs causing toxic effects as well as the shortage of minerals because of their reduced absorption [30]. Cadmium and 
lead are especially hazardous for children. Lead may result in serious negative effects on mental development, concentration ability, hearing, kidney function, blood chemistry, and cardiovascular system [37]. Also, cadmium has been found to cause an increased occurrence of cancer in mice [21].

The maximum residue level of lead in milk is $20 \mu \mathrm{g} / \mathrm{kg}$ [17]. According to Ziajka [20] the average lead content in the cow's milk ranges from 2 to $10 \mu \mathrm{g} / \mathrm{kg}$ and the content of cadmium from 1 to $10 \mu \mathrm{g} / 1$. In the study discussed, lead was actually found only in one of the analysed milk samples F $(5.24 \mu \mathrm{g} / 1)$. This milk came from an organic source and therefore should be free of this element. Lead is however a common pollution in the ecosystem and it easily penetrates into food, air, soil, and water; that is why it is almost impossible to totally eliminate it even in the organic production $[6,28]$. The content determined in this study is, however, permissible by law. In other cases, the quantity of lead was below the detection threshold of the method. Dobrzański et al. [13] showed that the average lead concentration was higher in the milk derived from the Upper Silesia industrial area $(42 \mu \mathrm{g} / \mathrm{kg})$ and from Lower Silesia, an area recognized as clean $(20 \mu \mathrm{g} / \mathrm{kg})$. The average content of lead in the Polish cow's milk identified by Bakuła et al. [2] was $12.8 \mu \mathrm{g} / \mathrm{kg}$. Higher concentrations of lead in the Polish milk were reported by Pietrzak-Fiećko and Smoczyński [35] - $89 \mu \mathrm{g} / 1$ and by Żmudzki et al. [46] $-21 \mu \mathrm{g} / \mathrm{kg}$, whereas lower concentrations were found by Szkoda et al. [43] $-3 \mu \mathrm{g} / \mathrm{kg}$, Dumna et al. [14] $-6 \mu \mathrm{g} / \mathrm{kg}$, and Król et al. [27] $-5 \div 10 \mu \mathrm{g} / \mathrm{kg}$. The concentration of lead in the milks analysed by researchers in other countries proved that there were some issues in matching the EU legal requirements. The Lithuanian raw milk examined by Valiukenaite et al. contained $5 \mu \mathrm{g} / \mathrm{kg}$ of lead [45]; the Spanish raw milk $5.23 \mu \mathrm{g} / 1$ [42]; the Japanese commercial milk - $12 \mu \mathrm{g} / \mathrm{kg}$ [36]; the South Korean skimmed and plain milk - respectively 13.86 and $3.35 \mu \mathrm{g} / \mathrm{kg}$ [23]; this was in compliance with the EU law. In comparison, the Chinese milk contained $35 \mu \mathrm{g} / \mathrm{kg}$ of lead [36], whereas the Egyptian raw milk - $66 \mu \mathrm{g} / \mathrm{kg}$ [16]; the Turkish raw milk $103 \mu \mathrm{g} / \mathrm{kg}$ [1]; and the Southern and Northern Croatian milk 58.7 and $36.2 \mu \mathrm{g} / \mathrm{l}$, accordingly [4].

The content of cadmium in the milks analysed was, in most cases, below the detection level. Only in the conventional milk samples A and B as well as in the organic milk $\mathrm{G}$, some small amounts of this element were found. The milk A and B, produced by the same manufacturer, contained, on average, 0.12 and $0.15 \mu \mathrm{g} / \mathrm{l}$, accordingly. The milk G contained only $0.04 \mu \mathrm{g} / 1$ of cadmium. Similarly, as in the case of lead, cadmium is a common pollution that is hard to be eliminated and, thus, small amounts of it may be found in every food product [6]. It can also be found in fertilizers [41]. It was evidenced that the contamination of food, including milk, is closely related to the degree of environmental pollution in which they are sourced $[5,13]$. Dobrzański et al. 
[13] showed that the average cadmium content was higher in the milk source from animals in the industrial area in Upper Silesia $(7.39 \mu \mathrm{g} / \mathrm{kg})$ and Lower Silesia, an area considered as clean $(3.88 \mu \mathrm{g} / \mathrm{kg})$. The concentrations of cadmium as determined in this study are among the low values presented in the reference literature. The average content of cadmium as reported by Bakuła et al. [2] in the Polish raw cow's milk was $7.9 \mu \mathrm{g} / \mathrm{kg}$. Lower concentrations of cadmium in the Polish milk were identified by Król et al. [27] - 2 $\div 6 \mu \mathrm{g} / \mathrm{kg}$, Żmudzki et al. [46] and Pietrzak-Fiećko and Smoczyński [35] $-3 \mu \mathrm{g} / \mathrm{kg}$. Enb et al. [16] determined $86 \mu \mathrm{g} / \mathrm{kg}$ of cadmium in the Egyptian raw milk; Valiukenaite et al. [45] $-4 \mu \mathrm{g} / \mathrm{kg}$ in the Lithuanian raw milk; Ayar et al. [1] $-17 \mu \mathrm{g} / \mathrm{kg}$ in the Turkish raw milk; Sola-Larranaga and Navarro-Blasco [22] $-0.4 \mu \mathrm{g} / \mathrm{l}$ in the Spanish raw milk; Qin et al. [36] - $0.001 \mu \mathrm{g} / \mathrm{g}$ in the Japanese commercial milk and 4 $\mu \mathrm{g} / \mathrm{kg}$ in the Chinese commercial milk, whereas Khan et al. [23] $2.22 \mu \mathrm{g} / \mathrm{kg}$ in the South-Korean skimmed milk and $2.38 \mu \mathrm{ng} / \mathrm{kg}$ in the plain milk. Cadmium concentrations measured in Croatia by Bilandžić et al. [4] ranged from 1 to $20 \mu \mathrm{g} / \mathrm{l}$; however, more than $80 \%$ of samples were below $5 \mu \mathrm{g} / \mathrm{l}$.

\section{Conclusions}

The results obtained have made it possible to formulate the following conclusions and observations:

1. In terms of the content of mineral substances, the organic and conventional milk do not differ significantly. The differences concerned only sodium and manganese. The organic milks contained, on average, statistically significantly less sodium and manganese than the conventional products.

2. High concentrations of iron in the milks A and B produced by the same producer resulted in a statistically significantly higher average concentration of this element in the conventional milks in comparison to the organic ones.

3. The sample F was the only variety of milk, in which lead was detected. Although the value determined was within the acceptable limits, the fact that this element was found in the organic milk raises concern.

4. Cadmium was determined in the two types of milk coming from the same company (samples A and B) and in the organic milk G, in which, however, the indicated concentration was at a relatively low level.

In this way, the formulated hypothesis reading: "the commercial organic milks differ significantly from the commercial conventional milks in relation to the content of mineral elements" was partially positively verified. 


\section{Acknowledgements}

The research was subsidized by the Ministry of Science and Higher Education grant for the maintenance of the research potential, awarded to the Faculty of Commodity Science and Product Management of the Cracow University of Economics.

\section{References}

[1] Ayar A., Sert D., Akin N.: The trace metal levels in milk and dairy products consumed in middle Anatolia-Turkey. Environ. Monit. Assess., 2009, 152, 1-12.

[2] Bakuła S., Pietrzak-Fiećko R., Tońska E., Gałgowska M., Miciński J.: Porównanie zawartości kadmu i ołowiu w mleku różnych gatunków zwierząt. Nauki Inż. i Technol., 2013, 3 (10), 9-17.

[3] Bergamo P., Fedele E., Iannibelli L., Marzillo G.: Fat-soluble vitamin contents and fatty acid composition in organic and conventional Italian dairy products. Food Chem., 2003, 82, 625-631.

[4] Bilandžić N., Dokić M., Sedak M., Solomun B., Varenina I., Knežević Z., Benić M.: Trace element levels in raw milk from northern and southern regions of Croatia. Food Chem., 2011, 127, 63-66.

[5] Boltea F., Bretan L., Ketney O., Moldovan C.: Heavy metals concentration in milk from the Baia Mare depression. J. Agroalim. Proc. Technol., 2008, 14 (2), 485-491.

[6] Borowiec M., Huculak M., Hoffman K., Hoffman J.: Ocena zawartości wybranych metali ciężkich w produktach spożywczych zgodnie z obowiązującym w Polsce prawodawstwem. Proc. EC Opole, 2009, 3 (2), 433-438.

[7] Butler G., Nielsen J.H., Slots T., Seal C., Eyre M.D., Sanderson R., Leifert C.: Fatty acid and fatsoluble antioxidant concentrations in milk from high- and low-input conventional and organic systems: Seasonal variation. J. Sci. Food Agric., 2008, 88, 1431-1441.

[8] Coni E., Bocca A., Ianni D., Caroli S.: Preliminary evaluation of the factors influencing the trace element content of milk and dairy products. Food Chem., 1995, 52, 123-130.

[9] Dangour A.D., Allen E., Lock K., Uauy R.: Nutritional composition and health benefits of organic foods - using systematic reviews to question the available evidence. Indian J. Med. Res., 2010, 131, 478-480.

[10] Dangour A.D., Lock K., Hayter A., Aikenhead A., Allen E., Uauy R.: Nutrition-related health effects of organic foods: A systematic review. Am. J. Clin. Nutr., 2010, 92, 203-210.

[11] De Castro C.S.P., Arruda A.F., Da Cunha L.R., De Souza J.R., Braga J.W.B., Dórea J.G.: Toxic Metals $(\mathrm{Pb}$ and $\mathrm{Cd})$ and their respective antagonists $(\mathrm{Ca}$ and $\mathrm{Zn})$ in infant formulas and milk marketed in Brasilia. Brazil. Int. J. Environ. Res. Public. Health., 2010, 7, 4062-4077.

[12] Dobrzański Z., Gorecka H., Opaliński S., Chojnacka K., Kołacz R.: Zawartość pierwiastków śladowych i ultraśladowych w mleku i krwi krów. Med. Weter., 2005, 61 (3), 301-304.

[13] Dobrzański Z., Skiba M., Brożyńska A., Kowalska-Góralska M.: Zawartość wybranych metali ciężkich w mleku przeżuwaczy (krów i kóz) z rejonów przemysłowych i czystych ekologicznie. Acta Sci. Pol. Med. Vet., 2009, 8 (1), 3-14.

[14] Dumna P., Pawlos M., Rudy M.: Zawartość metali ciężkich w wybranych produktach spożywczych województwa podkarpackiego. Bromatol. Chem. Toksyk., 2012, XLV (1), 94-100.

[15] Ellis K.A., Monteiro A., Innocent G.T., Grove-White D., Cripps P., McLean W.G., Howard C.V., Mihm M.: Investigation of the vitamins $A$ and $E$ and $\beta$-carotene content in milk from UK organic and conventional dairy farms. J. Dairy Res., 2007, 74, 484-491.

[16] Enb A., Abu Donia M.A., Abd-Rabou N.S., Abou-Arab A.A.K., El-Senaity M.H.: Chemical composition of raw milk and heavy metals behavior during processing of milk products. Glob. Vet., 2009, 3 (3), 268-275. 
[17] European Commission Regulation (EC) No 1881/2006 of 19 December 2006 setting maximum levels for certain contaminants in foodstuffs. Off. J. EU L 364, pp. 5-24, from 20.12.2006.

[18] Gartner L.M., Morton J., Lawrence R.A., O’Hare D., Schanler R.J., Eidelman A.I.: Breastfeeding and the use of human milk. Pediatrics, 2005, 115(2), 496-506.

[19] Grega T., Sady M., Farot A., Pustkowiak H.: Poziom wapnia, fosforu, laktozy i kwasu cytrynowego w mleku różnych ras. Rocz. Nauk. Zoot., 2000, Supl. 5, 27-30.

[20] Jaworski J., Kuncewicz A.: Składniki mineralne mleka. W: Mleczarstwo. T1. Red. S. Ziajka. Wyd. UWM w Olsztynie, Olsztyn 2008, ss. 82-85.

[21] Johnson M.D., Kenney N., Stoica A., Hilakivi-Clarke L., Singh B., Chepko G., Clarke R., Sholler P.F., Lirio A.A., Foss C.: Cadmium mimics the in vivo effects of estrogen in the uterus and mammary gland. Nat. Med., 2003, 9, 1081-1084.

[22] Khan N., Choi J.Y., Nho E.Y., Hwang I.M., Habte G., Khan M.A., Park K.S., Kim K.S.: Determination of mineral elements in milk products by inductively coupled plasma-optical emission spectrometry. Anal. Lett., 2014, 47 (9), 1606-1613.

[23] Khan N., Jeong I.S., Hwang I.M., Kim J.S., Choi S.H., Nho E.Y., Choi J.Y., Park K.S., Kim K.S.: Analysis of minor and trace elements in milk and yogurts by inductively coupled plasma-mass spectrometry (ICP-MS). Food Chem., 2014, 147, 220-224.

[24] Kodrik L., Wagner L., Imre K., Polyak K.F., Besenyei F., Husveth F.: The effect of highway traffic on heavy metal content of cow milk and cheese. Hung. J. Ind. Chem., 2011, 39 (1), 15-19.

[25] Komprda T.: Comparison of quality and safety of organic and conventional foods. Chem. Listy, 2009, 103, 729-732.

[26] Kouřimská L., Legarová V., Panovská Z., Pánek J.: Quality of cows’ milk from organic and conventional farming. Czech J. Food Sci., 2014, 32 (4), 398-405.

[27] Król J., Litwińczuk A., Brodziak A., Kędzierska-Matysek M.: Poziom ołowiu i kadmu w mleku krów utrzymywanych w różnych regionach Polski. Ochrona Środowiska i Zasobów Naturalnych, 2007, 31, 451-454.

[28] Krzywy I., Krzywy E., Pastuszak-Gabinowska M., Brodkiewicz A.: Ołów - czy jest się czego obawiać? Ann. Acad. Med. Stetin., 2010, 56 (2), 118-128.

[29] Litwińczuk Z.: Surowce zwierzęce - ocena i wykorzystanie. PWRiL, Warszawa 2004.

[30] Liu Z.P.: Lead poisoning combined with cadmium in sheep and horses in the vicinity of non-ferrous metal smelters. Sci. Total Environ., 2003, 309, 117-126.

[31] Maas S., Lucot E., Gimbert F., Crini N., Badot P.-M.: Trace metals in raw cow's milk and assessment of transfer to Comte cheese. Food Chem., 2011, 129 (1), 7-12.

[32] Michaelidou A.M.: Factors influencing nutritional and health profile of milk and milk products. Small Ruminant Res., 2008, 79, 42-50.

[33] Nyakairu G.W., Muhwezi G., Biryomumaisho S.: Assessment of heavy metals in milk from selected dairy farms and shops in Wakiso District, Uganda Suza. J. Nat. Soc. Sci., 2011, 1 (1), 36-52.

[34] Pieczonka W.: Towaroznawstwo mleka. AR w Krakowie, Rzeszów 1999.

[35] Pietrzak-Fiećko R., Smoczyński S.: Cadmium and lead contents in human milk, cow's milk and infant formulas. Pol. J. Nat. Sci., 2006, 21 (2), 1105-1112.

[36] Qin L.Q., Wang X.P., Li W., Tong X., Tong W.J.: The minerals and heavy metals in cow's milk from China and Japan. J. Health, 2009, 55 (2), 300-305.

[37] Salah F.A.A.E., Esmat I.A., Mohamed A.B.: Heavy metals residues and trace elements in milk powder marketed in Dakahlia Governorate. Int. Food Res. J., 2013, 20(4), 1807-1812.

[38] Schulzová V., Hajšlová J., Botek P., Peroutka R.: Furanocoumarins in vegetables: Influence of farming system and other factors on levels of toxicants. J. Sci. Food Agric., 2007, 87, 2763-2767. 
[39] Sikirić M., Brajenović N., Pavlović I., Havranek J.L., Plavljanić N.: Determination of metals in cow's milk by flame atomic absorption spectrophotometry. Czech J. Anim. Sci., 2003, 48 (11), 481 486.

[40] Slačanac V., Hardi J., Lučan M., Komlenić D.K., Krstanović V., Jukić M.: Concentration of nutritional important minerals in Croatian goat and cow milk and some dairy products made of these. Croat. J. Food Sci. Technol., 2011, 3 (1), 21-25.

[41] Smolders E.: Cadmium uptake by plants. Int. J. Occup. Med. Environ. Health, 2001, 14, 177-183.

[42] Sola-Larrańaga C., Navarro-Blasco I.: Chemometric analysis of minerals and trace elements in raw cow milk from the community of Navarra. Spain. Food Chem., 2009, 112, 189-196.

[43] Szkoda J., Nawrocka A., Kmiecik M., Żmudzki J.: Badania kontrolne pierwiastków toksycznych w żywności pochodzenia zwierzęcego. Ochrona Środowiska i Zasobów Naturalnych, 2011, 48, 475484.

[44] Tapiero H., Tew K.D.: Trace elements in human physiology and pathology: Zinc and metallothioneins. Biomed. Pharmacother., 2003, 57 (9), 399-411.

[45] Valiukenaite R., Stankeviciene M., Stankevicius H., Skibniewska K.A.: Lead and cadmium levels in raw cow's milk in Lithuania determined by inductively coupled plasma sector field mass spectrometry. Pol. J. Food. Nutr. Sci., 2006, 15/56 (SI 1), 243-246.

[46] Żmudzki J., Niewiadowska A., Szkoda J., Semeniuk S.: Toksyczne zanieczyszczenia żywności pochodzenia zwierzęcego w Polsce. Medycyna Pracy, 2001, 14, 35-40.

[47] Zurera-Cosano G., Moreno-Rojas R., Amaro-López M.: Effect of processing on contents and relationships of mineral elements of milk. Food Chem., 1994, 51, 75-78.

\title{
PORÓWNANIE ZAWARTOŚCI ZWIĄZKÓW MINERALNYCH W MLEKU KONWENCJONALNYM I EKOLOGICZNYM Z POLUDNIOWEJ POLSKI
}

\author{
Streszczenie
}

Mleko jest jednym z najważniejszych środków spożywczych i surowców w przemyśle spożywczym. Jako pierwszy kompletny pokarm dla młodych ssaków jest bioaktywny i zawiera wszystkie niezbędne składniki odżywcze. Uznaje się, że dzięki rolnictwu ekologicznemu uzyskuje się żywność o wysokiej jakości, wyprodukowaną w zrównoważonych warunkach, przy jednoczesnej ochronie środowiska naturalnego. Najnowsze badania dotyczące żywności i odżywiania nie potwierdzają jednak znacznych korzyści zdrowotnych związanych z konsumpcją produktów ekologicznych. Celem pracy była ocena i porównanie jakości komercyjnego krowiego mleka konwencjonalnego i ekologicznego w odniesieniu do zwartości wybranych składników mineralnych. Badania przeprowadzono na mleku krowim ekologicznym i tradycyjnym dostępnym na rynku w południowej Polsce. Próbki mleka analizowano pod względem zawartych w nich składników mineralnych, w tym wybranych metali toksycznych, przy użyciu absorpcyjnej spektrofotometrii atomowej płomieniowej, emisyjnej spektrometrii atomowej oraz absorpcyjnej spektrofotometrii atomowej w kuwecie grafitowej. Wyniki badań wskazują, że mleko ekologiczne i konwencjonalne nie różnią się istotnie w kontekście zawartości mikro- i makroelementów. Różnice dotyczyły jedynie zawartości sodu i manganu. Mleko ekologiczne zawierało ich średnio statystycznie istotnie mniej. Ponadto w jednym z rodzajów mleka ekologicznego wykryto obecność ołowiu, przy czym uzyskana wartość $(5,24 \mathrm{mg} / \mathrm{l}$ ) mieściła się w dopuszczalnych granicach. Kadm (w ilości 0,12 i 0,15 $\mu \mathrm{g} / \mathrm{l}$ ) został oznaczony w dwóch rodzajach mleka, pochodzących $\mathrm{z}$ tej samej firmy oraz w jednym mleku ekologicznym, w którym wykazane stężenie było na stosunkowo niskim poziomie $(0,04 \mu \mathrm{g} / 1)$.

Słowa kluczowe: mleko krowie, wartość odżywcza, metale, składniki odżywcze, żywność ekologiczna 